\title{
Intestinal Mass
}

National Cancer Institute

\section{Source}

National Cancer Institute. Intestinal Mass. NCI Thesaurus. Code C37903.

An abnormal growth in the small or large intestine. 